УДК 633.11:581.1:504.054.032.32

(C) 2012

Писаренко П. В., доктор сільськогосподарських наук, професор,

Колсснікова Л. А., асистент

Полтавська державна аграрна академія

\title{
ОСОБЛИВОСТІ ФОРМУВАННЯ ПРОВІДНОЇ СИСТЕМИ ПРОРОСТКІВ ПШЕНИЦІ ЗА СТРЕСОВОЇ ДІЇ НАФТИ
}

\section{Рецензент - доктор сільськогосподарських наук, професор Г. П. Жемела}

Визначено морфологічні прояви токсичних та інгібуючих властивостей компонентів сирої нафти поперечних зрізів листкової пластинки (далі-ЛП) проростків пшениці. Вивчено динаміку формування провідної системи ЛП четвертого листка модельної сільськогосподарської тест-культури на ранніх фазах онтогенезу за наявності стресового чинника. Встановлено, що при забрудненні трунту сирою нафтою в дозі 5 млкг спостерігається стимуляція розвитку елементів механічної тканини ЛП, щуо проявлясться в зростанні їх розмірів та кількості. Помірне забруднення (10-20 млкг) викликає асиметрію - тропізм розміщення судинноволокнистих пучків (СВП) відносно иентрального великого СВП, зменшення розміру великого СВП $i$ водночас збільшення иьього показника для середнього СВП, накопичення елементів механічної ткани-

ни. Збільшення дози нафтового забруднення до 50 мл/ка істотно впливає на розвиток провідної системи ЛП і призводить до появи у пустотах елементів ксилеми й флоеми середніх і великих СВП дрібнодисперсних мас, щуо, ймовірно, утворені продуктами дисиміляиії, деструкиії та катаболізму.

Ключові слова: трунт, мікроморфологія, судинно-волокнисті пучки, ксилема, флоема, листкова пластинка, нафтове забруднення.

Постановка проблеми. Життєдіяльність людини на Землі нерозривно пов'язана зі станом довкілля. Для видобувної промисловості взаємозв'язок із природними об'єктами являється основою функціонування. Саме через ці галузі відбувається поступання сировини в економіку, завдяки цим галузям зростає матеріальний розвиток усієї людської цивілізації. Очевидно, що значна частина накопичених екологічних проблем викликана також ними і потребує негайного пошуку шляхів її поліпшення. Нафтова промисловість за шкідливістю впливу на оточуюче середовище займає третє місце із 130 підприємств сучасного виробництва [3]. В останні роки на Полтавщині, в Україні і в світі в цілому погіршення екологічних умов, зокрема дедалі зростаюча площа нафтозабруднених земель сільськогосподарського призначення, є однією 3 найак- туальніших проблем, що призводить до збільшення ризику втрат гарантованих високих урожаїв або навіть повної загибелі рослин $[1,7]$. За таких обставин дослідження негативного впливу компонентів нафти на сільськогосподарські культури, вивчення їх стійкості до несприятливих умов довкілля в останній час є об'єктом особливої уваги науковців.

Аналіз основних досліджень і публікацій, у яких започатковано розв'язання проблеми. Результати повних комплексних досліджень забруднення агроекосистем $[4,8]$ дозволяють стверджувати аспект транслокації нафтових вуглеводнів із грунту у сільськогосподарські рослини. Органічні речовини, як доведено, акумулюються в тканинах живих організмів, негативно впливаючи на процеси метаболізму, подавляючи важливі фізіологічні функції рослин, порушуючи нормальне протікання біохімічних реакцій, знижуючи кількість і якість отриманої продукції $[9,11,12]$. Однак слід зазначити, що не дивлячись на досить велику кількість науково обгрунтованої інформації з питань надходження та впливу нафтопродуктів на систему «грунт - рослина» для агроекосистем залишається відкритим у зв'язку із вивченням процесів росту, розвитку та продуктивності в конкретних умовах. Спеціальні дослідження, що стосується безпосередньо Полтавщини, у цьому плані тільки-но розпочалися $[2,6]$. Ми ж у своїх експериментах спостерігали зміну анатомо-морфологічних показників за наявності короткочасового впливу стресора (сирої нафти Решетняківського родовища Полтавщини) на мікроморфологічному й морфометричному рівні ранньої стадії вегетації.

Мета досліджень - динаміка особливостей формування провідної системи проростків пшениці ярої залежно від вмісту сирої нафти в грунті.

Методика проведення досліджень. Було досліджено мікроморфологію четвертого листка проростків пшениці ярої, вирощених на грунтах, забруднених сирою нафтою в таких дозах: 5,10 , $20,30,40,50$ мл/кг. Для мікроскопічних дослі- 
джень вирізали центральну частину листкової пластинки (далі - ЛП) шириною 1-2 мм у десяти проростків у шестиразовій повторності. Отримані зразки ЛП обробляли за класичною методикою приготування препаратів для електронної мікроскопії [5]. Світлооптичні дослідження зрізів ЛП, забарвлених метиленовим синім і фуксином, проводили за допомогою мікроскопа XS-4130. На основі цих результатів визначали стимулюючий інгібуючий і резистентний ефекти впливу різних доз нафтового забруднення грунту на розвиток ЛП проростків пшениці ярої.

Результати дослідження. На поперечних зрізах ЛП четвертого листка проростків пшениці має «ввігнуту форму». Це свідчить про те, що на ранніх стадіях розвитку, листя надземних пагонів пшениці «згорнуті» у вигляді «напівкільця». Зовнішній контур ЛП утворює багаточисленні гребені та заглиблення. По обидві сторони найбільшого центрального гребеня симетрично розташовані заглиблення, за якими послідовно розміщені гребені та заглиблення. Найбільша товщина ЛП у контролі (норма) визначається на вершині центрального гребеня (250 мк), а найменша товщина ЛП виявляється в глибині впадини на краю листка (80 мк). Внутрішній контур ЛП помірно хвилястий. Як свідчать проведені дослідження, між зовнішнім та внутрішнім шарами епідермісу ЛП розміщена хлоренхіма, пронизана повздовжніми провідними пучками та елементами механічної тканини. Провідні пучки - залежно від будови - поділяються на великі (В), середні (С) та малі (М). Великі СВП містять крупні судини, що виконують функцію водопостачання й постачання мінеральних речовин від кореневої системи проростків до клітин паренхіми. Крупні судини формують ксилему провідних пучків. Багаточисленні дрібні судини утворені збиральними трубками, по яких проходить відтік продуктів асиміляції від клітин хлоренхіми листка в інші вегетативні органи проростків пшениці. Збиральні трубки формують флоему провідних пучків. Великі СВП містять досить розвинуту ксилему. У середніх СВП відносні об'єми ксилеми і флоеми приблизно однакові, а малі СВП складаються, переважно, $з$ елементів флоеми. В та С СВП оточені клітинами, які формують внутрішню і зовнішню піхви. Остання утворена великими клітинами мезофілу, в цитоплазмі яких виявлені поодинокі зерна хлорофілу. Анатомічне співвідношення в ЛП проростків пшениці ярої СВП можна записати у вигляді наступного співвідношення: $3 \mathrm{M}-1 \mathrm{C}-3 \mathrm{M}-1 \mathrm{~B}-$ $3 \mathrm{M}-1 \mathrm{C}-3 \mathrm{M}$ (1). Формула (1) свідчить про си- метричне розташування СВП відносно центральної жилки (В). Клітини механічної тканини утворюють тонкі механічні волокна, які розміщені парами на вершині гребеня ЛП, щільно контактуючи із розширеною основою волоскових епідермальних клітин. Значна кількість механічних волокон розміщена на кінцях ЛП. Елементи механічної тканини нами не виявлені в зоні розташування малих СВП. У зоні розміщення гребенів ЛП спостерігається безпосередній контакт облягаючих клітин СВП з макропорою. Це, очевидно, сприяє дифузії речовин і транспірації їх у напрямку СВП ↔ облягаючих клітини $\leftrightarrow$ макропора $\leftrightarrow$ продихи $\leftrightarrow$ повітряне середовище. За нафтового забруднення грунту (5 мл/кг) у ЛП суттєво збільшується кількість елементів механічної тканини. Діаметр зрізу великого СВП разом із зовнішньою піхвою становить 120-125 мк, тоді як за норми даний показник дорівнює 95-100 мікронів. Загальна кількість СВП, що пронизують у повздовжньому напрямі ЛП, дорівнює 15, по 7 пучків, які розташовані симетрично відносно центрального СВП. Анатомічний показник співвідношення кількості пучків дорівнює: $3 \mathrm{M}-$ $1 \mathrm{C}-3 \mathrm{M}-1 \mathrm{~B}-3 \mathrm{M}-1 \mathrm{C}-3 \mathrm{M}$ (2). Формула (2) свідчить про симетричне розташування СВП відносно центрального СВП. Суттєве збільшення кількості механічних волокон спостерігається зверху та знизу В і С СВП. Поблизу малих СВП і на краях ЛП кількість елементів механічної тканини більша, ніж у контрольній групі. Анастомози між СПВ не виявлені. За нафтового забруднення грунту (10-20 мл/кг) порівняно 3 нормою у ЛП спостерігається асиметрія - тропізм розміщення СВП відносно центрального СВП. 3 одного боку центральної жилки визначається 7, а 3 іншої 6 середніх і малих СВП. Змінюється анатомічне співвідношення середніх i малих СВП: 3 однієї сторони від СВП це співвідношення представлено у вигляді $1 \mathrm{M}-$ $1 \mathrm{C}-1 \mathrm{M}-1 \mathrm{C}-3 \mathrm{M}-1 \mathrm{~B}$, а 3 іншої дане співвідношення дорівнює $1 \mathrm{~B}-3 \mathrm{M}-1 \mathrm{C}-2 \mathrm{M}$ (3). Клітини зовнішньої піхви СВП деформовані, кутоподібної форми, що вказує на їх дегідратацію. Діаметр зрізу центрального СВП разом із зовнішньою піхвою становить 70-72 мк, що в 1,4 разу менше за норму (100 мк). Поперечник середнього СВП складає 65 мк (за норми даний показник дорівнює 76 мк). Діаметр зрізу малого СВП становить $\approx 33$ мк, що в межах похибки не відрізняється від норми. Результати вимірювань свідчать, що в умовах нафтового забруднення грунту (10-20 мл/кг) у ЛП відбувається зменшення розміру великого СВП і 
водночас збільшення розміру середнього СВП. У ЛП спостерігається збільшення кількості елементів механічної тканини. Над центральним і середніми СВП залягає механічна тканина, що складається з багатьох склеренхіматичних волокон, стінки яких помітно потовщені. У деяких препаратах ЛП елементи механічної тканини утворюють зв'язок між клітинами епідермісу i зовнішньою піхвою середніх СВП. Клітини зовнішньої піхви значно деформовані. Навколо малих СВП механічна тканина не виявляється. За нафтового забруднення грунту (30 мл/кг) значно зменшується ширина ЛП. Кількість СВП, що пронизують мезенхіму, зменшується від 15 (у нормі) до 13. Анатомічне співвідношення малих і середніх СВП дорівнює: $2 \mathrm{M}-1 \mathrm{C}-3 \mathrm{M}-1 \mathrm{~B}$ (4). Таким чином, ширина листкової пластинки менше контрольних значень на 150-200 мк. Не зважаючи на суттєве зменшення ширини ЛП, іiі максимальна товщина на вершині центрального (великого) гребеня складає 210 мк. Цифрові значення цього метричного показника залишаються незмінними не зважаючи на те, що нафтове забруднення грунту збільшується від 10 мл/кг до 30 мл/кг грунту. Найменша товщина ЛП, в межах похибки вимірювань, стабілізується, і на краєві ЛП в глибині впадини складає 72-75 мк. ЛП має типову «гофровану» будову. Висота гребенів поступово зменшується в напрямку від центра ЛП до їі країв. Мезенхіма ЛП пронизана впродовж розташованими СВП, відстань між якими менша, ніж у контрольних зразках. У малих СВП, розміщених по краях ЛП, виявляються елементи ксилеми. Збільшення кількості цих елементів (особливо в периферично розміщених малих СВП) свідчить про недостатнє надходження води і водорозчинних мінеральних сполук із кореневої системи рослин у вегетативні органи, і передусім, до листків. Порівняно з нормою, в ЛП проростків пшениці зменшуються розміри всіх СВП. Так, поперечник центрального СВП дорівнює 80 мк, що в 1,27 разу менше контрольного значення. Поперечник середнього СВП складає 64 мк, що в 1,1 разу менше норми. Залишається незмінним тільки розмір поперечних зрізів малих СВП, що дорівнюе 30-33 мк. Однак на краю ЛП поперечник малого СВП збільшується до 40-45 мк внаслідок появи в його складі елементів ксилеми. Компоненти механічної тканини мають типову будову. Найбільша їх кількість виявляється зверху та знизу центрального й середніх СВП. За нафтового забруднення грунту (40-50 мл/кг) мезенхіма ЛП пронизана СВП, кількість яких 12 (рідко 13), за норми - 15. Спостерігається асиме- тричне розміщення СВП відносно центральної жилки. 3 однієї їі сторони кількість СВП - 6 (іноді 7), а з протилежної - 5. Анатомічне співвідношення середніх і малих СВП у ЛП різних проростків пшениці становить: 2(3)M $-1 \mathrm{C}-3 \mathrm{M}$ - $1 \mathrm{~B}-3 \mathrm{M}-1 \mathrm{C}-1 \mathrm{M}$ (5). Отримані дані свідчать про зменшення кількості СВП і ширини ЛП проростків пшениці на грунтах із значним забрудненням сирою нафтою. Суттєво зменшуються розміри поперечного зрізу великих і середніх СВП. Так центральний провідний пучок разом із клітинами зовнішньої піхви у поперечному перерізі має діаметр 50-55 мк, у той час, як у контрольних зразках ЛП цей показник майже вдвічі більший і дорівнюе 100-102 мк. Поперечний розмір середнього СВП склав 35-40 мк, що також значно менше контрольних значень (70 мк). Величини діаметра малих СВП не відрізняється від норми і дорівнює 30-33 мк. У пустотах елементів ксилеми і флоеми середніх та великих СВП простежуються дрібнодисперсні маси, що, ймовірно, утворені продуктами дисиміляції, деструкції та катаболізму. Результати проведених морфологічних досліджень переконливо свідчать про те, що в умовах значного нафтового забруднення грунту (40-50 мл/кг) поодинокі проростки пшениці ярої через деякий час гинуть, а прикореневі листки відмирають і руйнуються.

\section{Висновки:}

1. Проведені мікроскопічні дослідження переконливо свідчать про те, що різні дози нафтового забруднення грунту неоднаково впливають на розвиток вегетативних органів проростків пшениці ярої.

2. Встановлено, що при забрудненні грунту сирою нафтою в дозі 5-10 мл/кг спостерігається стимуляція процесів розвитку елементів механічної тканини ЛП, що проявляється у зростанні їх розмірів і кількості структурних елементів.

3. Помірне забруднення (10-20 мл/кг) викликає асиметрію - тропізм розміщення СВП відносно центрального великого СВП, зменшення розміру великого СВП і водночас збільшення цього показника для середнього СВП. Не дивлячись на зменшення розмірів СВП, спостерігається збільшення кількості елементів механічної тканини. Це свідчить про наявність резистентності - стійкості проростків пшениці ярої до впливу помірного нафтового забруднення грунту.

4. Забруднення родючого шару грунту нафтою понад 30 мл/кг суттєво впливає на розвиток провідної системи ЛП. Органічні речовини сирої нафти опосередковано інгібують процеси анабо- 
лізму в клітинах ЛП, володіють деструктивними властивостями і призводять до появи у пустотах елементів ксилеми й флоеми середніх і великих СВП дрібнодисперсних мас.

5. Результати досліджень дали змогу встано-

\section{БІБЛІОГРАФІЯ}

1. Звіт про стан навколишнього природного середовища в Полтавській області у 2009 році. Полтава: Державне управління екології та природних ресурсів у Полтавській області, 2010. $117 \mathrm{c}$.

2. Колєснікова Л. А. Зміна будови листкової пластинки та іiі епідермального шару у проростків пшениці ярої, вирощених на нафтозабрудненому грунті / Л. А. Колєснікова // Вісник Полтавської державної аграрної академії. - 2011. - №3 C. $162-169$.

3. Мотузова В. Г. Международная научная конференция «Современные проблемы загрязнения почв» / В. Г. Мотузова // Почвоведение. 2005. - №5. - С. 634-637.

4. Никифорова Е. М. Полициклические ароматические углеводороды в выщелоченных черноземах и серых лесных почвах природных и техногенных ландшафтов / Е. М. Никифорова, И. С. Козин, Т. А. Теплицкая // Почвоведение. - 1989. №2. - C. 70-78.

5. Пиз Д. Гистологическая техника в электронной микроскопии / Д. Пиз. - М.: ИЛ., 1983 - 163 с.

6. Писаренко П. В. Оцінка екологічного стану сільськогосподарських угідь Полтавської області вити, що грунти 3 помірним (до 20 мл/кг) нафтовим забрудненням можна використовувати для землекористування під сільськогосподарські культури, насамперед пшениці ярої.

/ П. В. Писаренко, О. О. Ласло // Вісник Полтавської державної аграрної академії. - 2009. - №2. - C. 23-25.

7. Рудько Г. І. Екологічна безпека навколишнього природного середовища України. Контури проблеми / Г. І. Рудько, Б. Ю. Депутат // Екологія довкілля та безпека життєдіяльності. - 2003. - №4. - С. 22-28.

8. Шурубор Е. И. Полициклические ароматические углеводороды в системе «почва - растение» района нефтепереработки (Пермское Прикамье) / Е. И. Шурубор // Почвоведение. - 2000. №12. - C. 1509-1514.

9. Adam G. The effect of diesel fuel on common vetch (Vicia sativa L.) plants / G. Adam, H. Duncan // Environ. Geochem. Hlth. - 2003. - V. 25. P. 123-130.

11. Chaineau C. H., Morel J. L., Oudot J. Biodegradation of fuel oil hydrocarbons in the rhizosphere of maize // J. Environ. Qual. - 2000. V. 29, №2. - P. 569-578.

12. Kaimi E., Mukaidani T., Tamaki M. Screening of twelve plant species for phytoremediation of petroleum hydrocarbon-contaminated soil // Plant Prod. Sci. - 2007. - V. 10, №2. - P. 211-218. 